\title{
Experimental infection of Cysticercus fasciolaris in laboratory animals
}

\author{
by B. B. SINGH * and B. V. RAO, \\ Post-Graduate College of Animal Sciences, Indian Veterinary Research Institute, \\ Izatnagar, U.P. (India)
}

\section{Summary}

\begin{abstract}
Albino rats, albino mice, guinea pigs, rabbits and hamsters were fed with eggs of Taenia taeniaeformis, to study the development of Cysticercus fasciolaris under experimental conditions. Very few cysts developed in aged albino rats while rats of four weeks age were found to be most susceptible to the infection. Adult mice could not be infected but these of four weeks age could harbour quite a good number of cysts. Both adults and young guinea pigs and rabbits could not be infected. Adult hamsters were found to be refractory to the infection.
\end{abstract}

\section{Résumé}

Des rats albinos, des souris albinos, des cobayes, des lapins et des hamsters ont été infestés avec des œufs de Taenia taeniaeformis, afin d'étudier le développement de Cysticercus fasciolaris, dans des conditions expérimentales. Un très petit nombre de kystes se sont développés chez les rats albinos âgés, tandis que les jeunes rats se montrent plus sensibles à l'infection. Les souris adultes ne s'infestent pas, mais celles de 4 semaines présentent un bon nombre de kystes. Les cobayes, de même que les lapins, jeunes ou adultes, ne peuvent s'infester. Les hamsters adultes se montrent réfractaires à l'infection.

* Present address : Lecturer, Deptt. of Parasitology, University of Udaipur, College of Veterinary and Animal Science, Bikaner (Rajasthan) India. 


\section{Introduetion.}

Cysticercus fasciolaris, the larval stage of Taenia taeniasformis of cats and other felines, occurs mostly in the liver of rats and mice, but rabbits, squirrels, musk-rats and other rodents may also serve as intermediate hosts. Taenia taeniacformis infection has been reported in a child in the Argentine (Bacigalupo, 1922), so the parasite has zoonotic importance as well.

In this study, different species of laboratory animals were infected with the eggs of $T$. taeniaeformis in order to determine the difference in susceptibility of various laboratory animals.

\section{Materials and methods.}

Albino rats, albino mice, rabbits, guinea pigs and hamsters were usec in these studies. The rats and mice were maintained on wet flour and milk, while rabbits and guinea pigs were given germinated gram and greens. The hamsters were fed with crushed wheat, jowar, bengal gram, supplemented with yeast and milk. Besides $15 \mathrm{~g}$. of above mixture, lettuce leaves and germinated grams were also given to hamsters. All the animals were laboratory bred and were from the colonies free from natural infection of $T$. taeniaeformis as revealed from the autopsy of several animals, before the start of each experiment.

Infective material was obtained at autopsy of cats experimentally infected with T. taeniaeformis. The last four gravid segments containing mature eggs were used. Viability of eggs was checked before the onset of each experiment. Usually the animals were given 300 to 400 eggs, suspended in $0.3 \mathrm{ml}$ of physiological saline while older albino rats received 100 to 150 eggs.

A tuberculin syringe without the needle was used to infect the animals but for mice, a blunt needle was fitted to the syringe. The animals were killed at different stages of infection and the development of larvae was recorded.

\section{Results.}

\section{Albino Rats :}

i) Older albino rats: Adult rats weighing approximately $150 \mathrm{~g}$. were used. Of the seven adults autopsied 2 to 3 months after infection, four failed to become infected, one developed three cysts and the other two developed one cyst each. Four uninfected controls were free from any infection while the four infected control rats (aged four weeks) developed 208 to 352 cysts.

ii) Younger albino rats: A batch of 38 rats about 4 weeks old was used. This age group was found to be highly susceptible since the rats developed more number of cysts. The number of cysts developed varied from 250 to 322 in the rats autopsied at various levels of infection till 65 days. This group of rats also 
served as control for assessing the infectivity of eggs, as all the other laboratory animals were infected the same day. The four uninfected control rats (about four weeks old) were found to be free from infection, when autopsied at various levels of infection till 65 days.

ALbINo MICE :

i) Older albino mice: Twenty-five adult albino mice were infected and three mice were autopsied after every ten days till 60 days of infection but all were negative for this infection.

ii) Younger albino mice: Twenty-five albino mice of about 4 weeks of age were infected. Three mice were autopsied after every ten days till 60 days. The number of cysts developed varied from 150 to 265 .

GUINEA PIGS :

i) Three adult guinea pigs were infected. Two animals were autopsied 50 days and the other one 60 days after infection. None of these animals developed any cysticerci either in the liver or in other organs.

ii) Three young guinea pigs about 4 weeks of age were infected. Two guinea pigs had natural death 37 days after infection while the other one was autopsied 60 days after infection. None of the animals could take up any infection.

RABBITS :

i) Four adult rabbits were used. Two rabbits were autopsied 50 and 60 days and the other two by 127 days after infection. None of them developed any cysticerci in any of the organs.

ii) Four young rabbits about 4 weeks of age were infected. All of them were autopsied 63 days after infection. All were found to be refractory to this infection. HAMSTERS :

Only six adult hamsters were used in this work. One hamster died 18 days after infection and the second one was autopsied 36 days after infection, two hamsters were autopsied 119 days after infection and the last two by 147 day but they did not develop any cysticerci in the liver or in other organs.

\section{Discussion.}

Greenfield (1942) studied the Cysticercus burden of rats in various age groups and contended that the youngers rats, less than 25 days and older than 60 days, were completely immune to this infection. Dow and Jarrett (1960) recorded that younger mice are more susceptible than the adults to this infection. Schultz and Andreev (1960) observed that mice between the age of 25 to 30 days will have increased susceptibility than younger or older groups. In the present studies, it was observed 
that four weeks old albino rats and albino mice, were more susceptible to this infection and the percentage of cystic development was much higher than the older groups which is in accordance with the work of above mentioned workers.

Olivier (1962) was successful in detecting a few larvae in guinea pigs but in no case it was living and not bigger than $1.0 \mathrm{~mm}$. In the present study, no cysts could be detected either in the younger or in adult guinea pigs.

Joyeux and Co-workers as quoted by Mahon (1954) has recorded Cysticercus fasciolaris in the liver of rabbit in Algiers. Mahon (1954) was able to record the cyst in the back muscles of rabbits in North America. Smith and Jones (1961) and Smyth (1962) included rabbits also among the intermediate hosts of T. taeniaeformis, besides rats and mice. Our findings are in accordance with the work of Schiller (1949) who also could not experimentally infect young and aged rabbits.

The hamsters could not take up the infection and the present studies confirmed the findings of Schiller (1949) and Wantland (1953).

\section{AcKNOWLedGMent.}

The authors feel grateful to Dr. M. R. Dhanda, the then Director, Indian Veterinary Research Institute, Izatnagar (India) and to Dr. H. D. Srivastava, Asstt. Director and Head of Division of Parasitology, I.V.R.I., Izatnagar, for providing the necessary facilities.

\section{Bibliography}

Bacigalupo (J.), 1922. - Semna Med., 32, 302.

Dow (C.) et Jarret (W. F. H.), 1960. - Expt. Parasit., 10, 72.

Greenfield (S.), 1942. - J. Parasit., 38, 207.

Mahon (J.), 1954. - J. Parasit., 40, 696.

Olivier (L.), 1962. - J. Parasit., 48, 373.

Schiller (E. L.), 1949. - J. Parasit., 35, 37.

Schultz (R. S.) et ANDreev (A. N. K), 1960. - Trudi Inst. Zool. Akad. Nauk Kazakhkov $55, \mathrm{R}, 12,104$.

Smith (H. A.) et Jones (T. C.), 1961. - Veterinary Pathology, Lea and Febiger, Philadelphia.

SMYTH (J.D.), 1962. - Introduction to Animal Parasitology, English University Press, London.

Wantland (W. W.), 1953. - J. Parasit., 39, 667. 